\title{
The Discovery of Chromosome Trisomy 22: A Novel Chromosomal Feature of Siamang (Symphalangus syndactylus)
}

\author{
Sitthisak Jantarat ${ }^{1}$, Alongkoad Tanomtong, ${ }^{2,}$, Praween Supanuam², \\ Sarawut Kaewsri ${ }^{3}$ and Worapon Aengwanich ${ }^{4}$ \\ ${ }^{1}$ Biology Program, Department of Science, Faculty of Science and Technology, Prince of \\ Songkhla University (Pattanee), Muang, Pattanee 94000, Thailand \\ ${ }^{2}$ Genetics Program, Department of Biology, Faculty of Science, Khon Kaen University, \\ Muang, Khon Kaen 40002, Thailand \\ ${ }^{3}$ Progam in Appied Biology, Department of Science, Faculty of Science, Buriram Rajabhat \\ University, Muang, Buriram 31000, Thailand \\ ${ }^{4}$ Stress and Oxidative Stress Unit, Faculty of Veterinary Medicine and Animal Science, \\ Mahasarakham University, Muang, Mahasarakham 44000, Thailand
}

Received September 27, 2007; accepted May 8, 2008

\begin{abstract}
Summary For this knowledge, the discovery of the chromosome trisomy 22 in siamang (Symphalangus syndactylus) is the first report. To our scheme, blood sample was collected from one female of Khao Kheow Open Zoo (KKOZ), Chonburi province, Thailand. Chromosomes were prepared by lymphocyte cells culture at $37^{\circ} \mathrm{C}$ for $72 \mathrm{~h}$ then stained by $\mathrm{G}$ banding technique. The result indicated that diploid $(2 n)$ of siamang was 51 (one irregular chromosome was found). The autosome consists of 47 metacentric and submetacentric, 2 telocentric chromosomes. The X chromosome was metacentric chromosome. The increasing of one metacentric chromosome 22 lead to the presence of the irregular chromosome and the changing of $2 n=50$ to $2 n=51$. The augmentation of chromosome 22 was found in all metaphase cells of the entire study. We suggested that the chromosome increasing is a consequence from the non-disjunction in meiosis cell division.
\end{abstract}

Key words Chromosome, Trisomy 22, Siamang (Symphalangus syndactylus).

Animals in family Hylobatidae (gibbons) are small apes that live on trees and not come down to the ground. Its arms and fingers look like a hook for holding branch. Its activities usually in daytime. It eats fruit, treetop, flower, leaf and insect and lives along with group like a family with one married couple. Gibbons are exist in all parts of Thailand. There are 4 species, white-handed gibbon (Hylobates lar), dark-handed gibbon (Hylobates agilis), pileated gibbon (Hylobates pileatus) and siamang (Symphalangus syndactylus) (Parr 2003).

The autosomal trisomies have been reported in 11 nonhuman primates from eight different species (McClure et al. 1969, McClure 1972, Turleau et al. 1972, Andrle et al. 1979, Ruppenthal et al. 1983, Vigfusson et al. 1986, Ward et al. 1994, de Best et al. 1995, Moore et al. 1998, Best et al. 1999, Lear et al. 2001, Ruppenthal et al. 2004) (Table 1). There were many previous reports on cytogenetics of siamang including Bender and Chu (1963), Klinger (1963), Chiarelli (1972), Groves (1972), Couturier et al. (1982), Koehler (1995) and Muller et al. (2003). However, chromosome trisomy 22 in siamang has never been reported before. The chromosome trisomy 22 that we found is the novel chromosomal feature of siamang.

*Corresponding author, e-mail: tanomtong@hotmail.com 
Table 1. Autosomal trisomies have been reported in 11 nonhuman primates from eight different species

\begin{tabular}{|c|c|}
\hline Homology to human trisomy & Reference \\
\hline \multicolumn{2}{|l|}{ Human trisomy 13} \\
\hline $\begin{array}{l}\text { Pig-tailed macaque (Macaca nemestrina) } 43, \mathrm{XY},+16 \text { and cells with } \\
\text { other trisomies (variable karyotype) }\end{array}$ & Vigfusson et al. (1986) \\
\hline Long-tailed macaque (M. fascicularis) $43, \mathrm{XY},+16$ & Ward et al. (1994) \\
\hline Pig-tailed macaque (M. nemestrina) $43, \mathrm{XX},+16$ & Best et al. (1999) \\
\hline \multicolumn{2}{|l|}{ Human trisomy 17} \\
\hline Baboon (Papio hamadryas) 43, XX, +16 & Moore et al. (1998) \\
\hline \multicolumn{2}{|l|}{ Human trisomy 18} \\
\hline Pig-tailed macaque (M. nemestrina) number one $43, \mathrm{XX},+18$ & Ruppenthal et al. (1983) \\
\hline Pig-tailed macaque (M. nemestrina) number two $43, \mathrm{XX},+18$ & Ruppenthal et al. (1983) \\
\hline Pig-tailed macaque (M. nemestrina) number three $42, \mathrm{XX} / 43$, & \\
\hline $\mathrm{XX},+18$ (mosaic karyotype) & Ruppenthal et al. (1983) \\
\hline Rhesus monkey (M. mulatta) 43, XX, +18 & de Best et al. (1995) \\
\hline Bonobo (Pan paniscus) 49, XX, +17 & Lear et al. (2001) \\
\hline \multicolumn{2}{|l|}{ Human trosomy 21} \\
\hline Chimpanzee (P. troglodytes) $49, \mathrm{XX},+22$ & McClure et al. (1969) \\
\hline $\begin{array}{l}\text { Lowland gorilla (Gorilla gorilla) } 49, \mathrm{XY},+ \text { mar exact origin of } \\
\text { marker was not confirmed }\end{array}$ & McClure (1972) \\
\hline Orangutan (Pango pygmaeus) 49, XX, +22 & Andrle et al. (1979) \\
\hline
\end{tabular}

\section{Materials and methods}

Blood samples from the jugular vein were collected with aseptic technique from one female siamang which were kept in Khao Kheow Open Zoo (KKOZ), Chonburi province, Thailand and then applied for cytogenetic studies by lymphocyte culture of whole blood samples. The culture cells were treated with a colchicine-hypotonic-fixation-air-drying technique followed by G-banding with Giemsa's adapted from Rooney (2001) and Campiranon (2003). G-banding can provide an accuracy homologous chromosome of mammals. Twenty cells of each individual chromosome checks, karotyping and idiograming were accomplished by using a light microscope as previously described (Supanuam et al. 2007).

\section{Results and discussion}

According to the scheme, G-banding technique indicated that female siamang has $2 n=51$ instead of the normal $2 n=50$ (one irregular chromosome which different from the previous reports) (Bender and Chu 1963, Klinger 1963, Chiarelli 1972, Groves 1972, Couturier et al. 1982, Koehler et al. 1995, Muller et al. 2003).

Our results demonstrated that the autosome of female siamang consists of 47 metacentric and submetacentric chromosomes, 2 telocentric chromosomes (Fig. 1). The results are differ from Bender and Chu (1963), Klinger (1963) and Chiarelli (1972) that reported the 46 metacentric and submetacentric chromosomes, 2 telocentric chromosomes of siamang. The difference is resulted from the addition of metacentric autosome chromosome 22 that lead to trisomic. Therefore, this study is the first report on trisomic chromosome of siamang. For the sex chromosome, the results indicated that the $\mathrm{X}$ chromosome of female siamang was metacentric chromosome which is in agreement with Bender and Chu (1963), Klinger (1963) and Chiarelli (1972).

The karyotyping of metaphase cells from G-banding technique make a confirmation that the irregular chromosome was metacentric autosome 22. Moreover, that addition of chromosome 22 was found in all metaphase cells for the entire research. It is a result of the chromosome non-disjunction (meiosis I or II) which is in agreement with those the addition of human chromosome 13, 

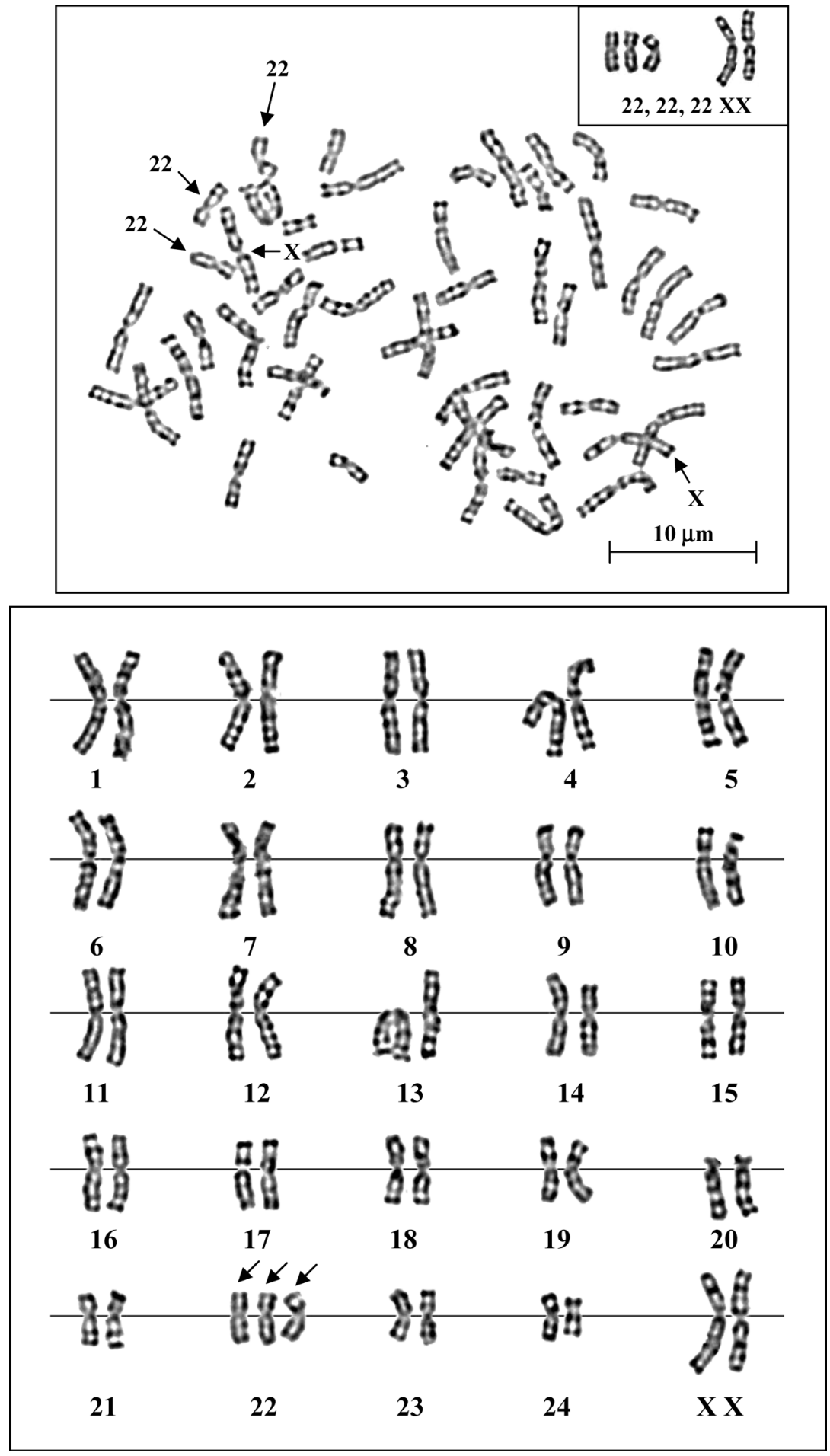

Fig. 1. Metaphase chromosome (top) and karyotype (bottom) of female siamang (Symphalangus syndactylus) $2 n=51$, by G-banding, chromosome trisomic 22 (arrows). 
$18,21, \mathrm{X}$ chromosome in male, $\mathrm{X}$ chromosome in female and $\mathrm{Y}$ chromosome in male and the irregular chromosome causes Patau's syndrome (47, +13), Edwards's syndrome $(47,+18)$, Down's syndrome $(47,+21)$, Klinefelter's syndrome $(47,+\mathrm{XXY}), \mathrm{XXX}$ syndrome $(47,+\mathrm{XXX})$ and $\mathrm{XYY}$ syndrome (47, +XYY) (Cumming 1988). The autosomal trisomies have been reported in 11 nonhuman primates from eight different species. Some of these animals have a marked similarity in phenotype to the homologous syndromes reported in humans. The chimpanzee, Pan troglodytes (McClure et al. 1969, McClure 1972) and an the orangutan, Pongo pygmaeus (Andrle et al. 1979) with trisomy 22 indicated both of some clinical and behavioral symptoms of human Down's syndrome. The great apes' chromosome 22 is homologous to human's chromosome 21 (Wienberg et al. 1992). The gorillas (Gorilla gorilla) which have the same chromosomal abnormality expressed both of normal morphological and behavioral characteristics (Turleau et al. 1972).

In this study, female siamang was born in Khao Kheow Open zoo (KKOZ) and separated feed from parents. Now it is 1 year old. For phenotype and behavior checking, it was similar to other siamang. We have no detail of its parents because of it was donated to the Zoo. Although we were not taken any action but we predicted that this siamang had abnormally oocyte results from unnatural synapsis of homologous chromosome in meiosis I. Then trivalent of Chromosome 22 was appeared and effected to chromosome separating in anaphase I. One chromosome piece was separated to one site while two chromosome pieces were separated to another site lead to normal and abnormal gamete, respectively.

\section{Conclusion}

In this study, siamang's chromosome number was $2 n=51$ which consists of 47 metacentric and submetacentric chromosomes, 2 telocentric chromosomes. The $\mathrm{X}$ chromosome was metacentric chromosome. The increasing of one metacentric chromosome 22 lead to the presence of the irregular chromosome and the changing of $2 n=50$ to $2 n=51$. We suggested that the chromosome increasing is a consequence from the non-disjunction in meiosis cell division.

\section{Acknowledgment}

The financial support from the Zoological Park Organization under the Royal Patronage of H.M. the King is gratefully acknowledged. We also thank Mr. Sopon Dumnui, Director of the organization and Dr. Sumat Kamolnaranath, chief of the Educational Division, for valuable help.

\section{Reference}

Andrle, M., Fielder, W., Rett, A., Ambros, P. and Schweizer, D. 1979. A case of trisomy 22 in Pongo pygmaeus. Cytogenet. Cell. Genet. 24: 1-6.

Bender, M. A. and Chu, E. H. Y. 1963. The chromosome of primate. In: Evolutionary and genetic biology of primate. Vol. 1 Academis Press, New York.

Best, R. G., Ruppenthal, G. C., Walker-Gelatt, C. G., Delio, P. J. and Moore, C. M. 1999. Trisomy 16 in a macaque with multiple congenital abnormalities: relationship to human trisomy 13. Cytogenet. Cell. Genet. 85: 87.

Campiranon, A. 2003. Cytogenetics. Bangkok: Department of Genetics, Faculty of Science, Kasetsart University, Thailand.

Chiarelli, B. 1972. The karyotypes of the gibbons. Gibbon and Siamang 1: 90-102.

Couturier, J., Dutrillaux, B., Turleau, C. and Grouchy, J. de. 1982. Comparative karyotyping of our gibbon species or subspecies. Ann. Genet. (Paris) 25: 5-10.

Cumming, M. R. 1988. Human Heredity. West Publishing Company: United States of America, St. Paul.

de Best, F. B. M., Uno, H., Luttrell, L. M., Meisner, L. F. and Jeannotte, L. A. 1995. Behavioral retardation in a macaque with autosomal trisomy and aging mother. Am. J. Ment. Retard. 100: 378-390.

Groves, C. P. 1972. Systematics and phylogeny of gibbons. In: Rumbaugh, D. M. (ed) Gibbon and Siamang, vol 1. Karger, Basel. 1-89. 
Klinger, H. P. 1963. The somatic chromosomes of some primate: Tupaia glis, Nyctiebus coucang, Tarisus bancanus, Cercocebus aterrimus, Symphalagus syndactilus. Cytogenetics 2: 140-151.

Koehler, U., Arnold, N., Wienberg, J., Tofanelli, S. and Stanyon, R. 1995. Genomic reorganization and disrupted chromosomal synteny in the siamang (Hylobates syndactylus) revealed by fluorescence in situ hybridization. Am. J. Phys. Anthropol. 97: 37-47.

Lear, T. L., Houch, M. L., Zhang, Y. W., Debnar, L. A., Sutherland-Smith, M. R., Young, L., Jones, K. L. and Benirschke, K. 2001. Trisomy 17 in a bonobo (Pan paniscus) and deletion of $3 \mathrm{q}$ in a lowland golilla (Gorilla gorilla): Comparison with human trisomy 18 and human deletion 4q syndrome. Cytogenet. Cell. Genet. 95: 228-233.

McClure, H. M., Belden, K. H., Pieper, W. A. and Jocobson, C. B. 1969. Autosomal trisomy in a chimpanzee. Resemblance to Down's syndrome. Science 165: 1010-1012.

—. 1972. Animal model for human disease: Down's syndrome (mongolism, trisomy 21). Am. J. Pathol. 67: $413-416$.

Moore, C. M., McKeand, J., Witte, S. M., Hubbard, G. B., Rogers, J. and Laland, M. M. 1998. Teratoma with trisomy 16 in baboon (Papio hamadryas). Am. J. Primatol. 46: 323-332.

Muller, S., Hollatz, M. and Wienberg, J. 2003. Chromosome phylogeny and evolution of gibbons (Hylobatidae). Hum. Genet. 113: 493-501.

Parr, J. W. K. 2003. Large Mammals of Thailand. Sarakadee Press: Bangkok, Thailand.

Ruppenthal, G. C., Caffery, S. A., Goodlin, B. L. Sackett, G. P., Vigfusson, N. V. and Peterson, V. G. 1983. Pig-tailed macaques (Macaca nemestrina) with trisomy X manifest physical and mental retardation. Am. J. Ment. Defic. 87: 471-476.

—, Moore, C. M., Best, R. G., Walker-Gelatt, C. G., Delio, P. J. and Sackett, G. P. 2004. Trisomy 16 in a pig-tailed macaque (Macaca nemestrina) with multiple anomalies and developmental delays. Am. J. Ment. Retard. 109: 9-20.

Rooney, D. E. 2001. Human Cytogenetics: Constitutional Analysis. Oxford University Press: Oxford.

Supanuam, P., Tanomtong, A. and Khunsook, S. 2007. Standardized karyotype and idiogram of the pileated gibbon, Hylobates pileatus (Primate, Hylobatidae) by G-banding and high-resolution technique. Cytologia 72: 189-194.

Turleau, C., de Grouchy, J. and Klein, M. 1972. Phylogenie chromosomique de I'homme et des primates hominiens (Pan troglodytes, Gorilla gorilla, et Pongo pygmaeus): Essai dereconstitution du caryotypes de I'ancestre commun. Annales de Genetique 15: 225-240.

Vigfusson, N. V., Dawson, R. J., Jones, J. F., Shaw, K. J., Lloyd, M. A., Ruppenthal, G. C. and Sackett, G. P. 1986. Mosaic variegated trisomy $(42, \mathrm{XY} / 43, \mathrm{XY}+$ variable $)$ in a male pig-tailed macaque monkey. Cytogenet. Cell. Genet. 42: $154-158$.

Ward, D. G., Miller, R. L., Johnson, E. H. and Lucas, J. N. 1994. Identification of trisomy in Macaca fascicularis by fluorescence in situ hybridization with a human chromosome 13 DNA library. Hum. Genet. 94: 247-251.

Wienberg, J., Stanyon, R., Jauch, A. and Cremer, T. 1992. Homologies in human and Macaca fuscata chromosomes revealed by in situ suppression hybridization with human chromosome specific DNA libraries. Chromosoma 101: 265-270. 